\title{
FAKTOR-FAKTOR ANAK DITERLANTARKAN DAN DAMPAKNYA (STUDI DI KOTA AMBON)
}

\author{
Oleh Nancy Rahakbauw*
}

\begin{abstract}
This paper aims to describe the factors that lead to neglect of children, as well as the impact experienced by children who are neglected. This study used a qualitative approach and descriptive analysis. Subjects were children who had been neglected by the age category 10 to 18 years old and their parents or family.

From the analysis of the research findings, it was shown that the triggers that lead to neglected children is a parental divorce and mistreatment received by children, as well as family economics and low parental education. The impact of divorce and abuse experienced by children led to the rights and needs of children are not even fulfilled properly and optimally. This situation eventually encourage children to do activities outside the home to become hawkers, washerman grave, domestic workers and motorcycle taxi drivers. By carrying out an activity or activities outside the home that takes time and effort, they do not have time to go to school.
\end{abstract}

Keywords: neglected children, children's rights, the needs of children, family problems

\begin{abstract}
Abstrak
Tulisan ini bertujuan menggambarkan faktor-faktor yang menyebabkan anak ditelantarkan, serta dampak yang dialami oleh anak yang ditelantarkan. Penelitian ini menggunakan pendekatan kualitatif dan bersifat deskriptif analisis. Subyek penelitian adalah anak-anak yang ditelantarkan dengan kategori usia 10 sampai 18 tahun dan orang tua atau keluarga.

Dari hasil analisis temuan penelitian didapatkan gambaran bahwa faktor pemicu yang menyebabkan anak terlantar adalah perceraian orang tua dan perlakuan salah yang diterima anak, serta ekonomi keluarga dan pendidikan orang tua yang rendah. Dampak perceraian dan perlakuan salah yang dialami anak menyebabkan hak dan kebutuhan anak terabaikan bahkan tidak terpenuhi secara layak dan optimal. Situasi ini akhirnya mendorong anak melakukan aktivitas di luar rumah dengan menjadi pedagang asongan, tukang cuci kuburan, pekerja rumah tangga dan tukang ojek. Dengan melaksanakan kegiatan atau aktivitas di luar rumah yang menyita waktu dan tenaga, mereka tidak memiliki waktu untuk bersekolah.
\end{abstract}

Kata Kunci: anak terlantar, hak-hak anak, kebutuhan anak, masalah keluarga

\section{Pendahuluan}

Anak adalah pewaris, penerus dan aset bangsa yang akan mengemban tugas bangsa dimasa yang akan datang. Bahkan secara dramatis dikatakan bahwa anak merupakan modal sosial dan ekonomi suatu bangsa. Dalam arti individual, anak bagi orang tuanya mempunyai nilai khusus yang penting pula yaitu sebagai penerus keturunan. Dari kedua aspek tersebut yang diharapkan adalah anak dapat tumbuh dan berkembang sebaikbaiknya, sehingga kelak menjadi orang dewasa yang sehat fisik, mental, dan psiko sosial sebagai sumber daya manusia.
Disamping sebagai pewaris ataupun modal dan penerus suatu keturunan, seorang anak juga memiliki hak asasi anak yang merupakan bagian dari hak asasi manusia yang termuat dalam Undang-Undang Dasar 1945 dan Konvensi Perserikatan Bangsa-Bangsa Tentang Hak Anak. Berpijak pada kedua hal tersebut, maka seorang anak berhak atas kelangsungan hidup, tumbuh dan berkembang, berpartisipasi serta berhak atas perlindungan dari tindak kekerasan dan diskriminasi serta hak sipil dan kebebasan. Oleh karena itu, anak diharapkan dapat menikamati setiap kehidupan yang dijalaninya dengan mendapat dukungan orang-orang yang 
mengasihinya terutama keluarga terdekatnya. Undang-Undang Nomor 23 Tahun 2002 Tentang Perlindungan Anak menyatakan bahwa anak adalah seseorang yang belum berusia 18 tahun (delapan belas tahun), termasuk yang yang berada dalam kandungan.

Berbicara atau mendiskusikan apapun tentang anak, tidak bisa dilepaskan dari konsep keluarga. Keluarga merupakan fondasi utama anak berpijak dan melangkah menatap masa depannya. Keluarga dalam hal ini keluarga inti terdiri dari ayah, ibu, kakak dan adik, sementara keluarga batih terdiri dari paman, bibi, kakek dan nenek serta anggota keluarga besar lainnya. Semua elemen dalam keluarga mempunyai tugas dan tanggung jawab dalam memberi perlindungan dan kasih sayang bagi seorang anak, sehingga anak dapat berkembang dan bertumbuh sesuai dengan usianya.

Dalam melewati fase-fase perkembangan dan pertumbuhannya anak banyak mengadopsi segala sesuatu dari lingkungannya, baik lingkungan internal maupun lingkungan eksternal. Sesuai dengan pertumbuhan dan perkembangannya anak membutuhkan atau mengharapakn suatu kondisi atau situasi yang nyaman, terlidungi dan juga merasa aman. John Locke (1632-1704) mengemukakan bahwa pengalaman dan pendidikan bagi anak merupakan faktor yang paling menentukan dalam perkembangan anak. Isi kejiwaan anak ketika dilahirkan adalah ibarat secarik kertas yang masih kosong, disinilah orangtua mempunyai pengaruh yang sangat besar dalam mengisi kehidupan seorang anak mulai dari bayi hingga dewasa. Menurut Undang-Undang Nomor 4 Tahun 1979 Tentang Kesejahteraan Anak, orangtua yang pertama-tama bertanggung jawab atas terwujudnya kesejahteraan anak baik secara rohani, jasmani maupun sosial. Selain itu juga, orang tua, menurut Undang-Undang Nomor 23 Tahun 2002 Tentang Perlindungan Anak, adalah ayah dan/atau ibu kandung, atau ayah dan/atau ibu tiri, atau ayah dan/atau ibu angkat. Jadi orang tua dalam hal ini keluarga merupakan lingkungan kehidupan yang dikenal anak untuk pertama kalinya di dalam berinteraksi maupun berelasi dengan lingkungan sosialnya. Pembangunan karakter, pembangunan fisik maupun pembangunan intelektual seorang anak sangatlah penting, oleh karena itu keluarga dalam lingkup yang lebih kecil memiliki kontribusi yang besar dalam menciptakan suatu bangsa yang berakhlak mulia dan memiliki integritas yang tinggi melalui anak dalam tumbuh kembangnya sehingga kehidupan sejahtera yang ingin dicapai dapat terpenuhi.

Realitas kehidupan anak saat ini menjadi fenomena tersendiri. Di berbagai media baik media elektronik maupun media cetak, masalah anak semakin hari semakin memprihatinkan, banyak terjadi kekerasan dan kondisi tidak baik yang dialami oleh anak: pemerkosaan, anak jalanan, anak yang diperdagangkan, anak yang ditelantarkan dan juga anak putus sekolah. Situasi dan kondisi ini memberikan dampak yang buruk bagi perkembangan dan pertumbuhan anak. Anak menjadi obyek yang mudah diperlakukan secara semena-mena tanpa memikirkan kondisi psikologisnya. Karena itu, penelitian ini mencoba meneliti tentang faktor-faktor penyebab anak ditelantarkan dan dampak yang dialami oleh anak yang ditelantarkan.

\section{Tinjauan Teoritis}

\subsection{Anak Terlantar dan Ciri-Ciri Anak Terlantar}

Anak adalah seseorang yang masih kecil dan membutuhkan perhatian dan kasih sayang dari orang dewasa. Dalam tumbuh kembangnya, anak senantiasa berada dalam lingkungan orang dewasa untuk memperoleh perlindungan dan kenyamanan dalam menjalani fase-fase kehidupannya. Anak terlantar menurut kamus besar bahasa Indonesia adalah anak yang tidak terpelihara, tidak terawat, tidak terurus dan serba tidak berkecukupan. Seorang anak dikatakan telantar, bukan karena sekedar ia tidak lagi memiliki salah satu orang tua atau kedua orang tuanya. Tetapi, telantar disini juga dalam pengertian ketika hak-hak anak untuk tumbuh kembang secara wajar, untuk memperoleh pendidikan layak, dan untuk memperoleh pelayanan kesehatan yang memadai, tidak terpenuhi karena kelalaian, ketidakmengertian orang tua, ketidakmampuan atau ketidaksengajaan (Suyanto, 2010). Undang-Undang Nomor 23 Tahun 2002 Tentang Perlindungan Anak Pasal 1 menyatakan bahwa anak adalah seseorang yang belum berusia 18 (delapan belas) tahun, termasuk anak yang masih dalam kandungan. Lebih lanjut dikatakan dalam undang-undang tersebut bahwa anak terlantar adalah anak yang tidak terpenuhi kebutuhannya secara wacar, baik fisik, mental, spiritual, maupun sosial. Merujuk Kamus Besar Bahasa Indonesia, pengertian anak secara etimologis diartikan sebagai manusia yang masih kecil ataupun manusia yang belum dewasa. Selanjutnya pengertian anak terlantar dijabarkan Robert L. Balker dalam Social Work Dictionary (1999: 72) sebagai berikut: 
"Child Neglect is the failure of those responsible for the care of a minor to provide the resources needed for healthy physical, emotional, and social development. Exemples of neglect include inadequate nutrition, inproper supervison, or no provisions for educational or health care requirements".

Penelantaran merupakan salah satu bentuk dari kekerasan dengan cara membiarkan anak dalam situasi gizi buruk, kurang gizi (malnutrisi), tidak mendapatkan perawatan maksimal, serta memaksa anak pada berbagai jenis pekerjaan yang membahayakan pertumbuhan dan perkembangan anak, seperti pengemis, pengamen, anak jalanan, buruh pabrik, pembantu rumah tangga, dan pemulung. Dalam hal ini, Rusmil Kusnandi (2004: 59) menjelaskan apabila orang tua tidak dapat memenuhi kebutuhan anak, baik kebutuhan fisik, psikis ataupun emosi, tidak memberikan perhatian dan sarana untuk berkembang sesuai dengan tugas perkembangannya juga merupakan tindakan penelantaran.

Termasuk didalamnya penelantaran anak adalah:

a. Penelantaran untuk mendapatkan perawatan kesehatan, misalnya mengingkari adanya penyakit serius pada anak.

b. Penelantaran untuk mendapatkan keamanan, misalnya cedera yang disebabkan kurangnya pengawasan dan situasi rumah yang membahayakan.

c. Penelantaran emosi, tidak memberikan perhatian kepada anak, menolak keberadaan anak.

d. Penelantaran pendidikan, anak tidak mendapatkan pendidikan sesuai dengan usiannya, tidak membawa anak ke sarana pendidikan atau menyuruh anak mencari nafkah untuk keluarga, sehingga terpaksa putus sekolah.

e. Penelantaran fisik, yaitu jika anak tidak terpenuhi kebutuhan makan, pakain, atau tempat tinggal yang layak untuk mendapatkan tumbuh kembang secaa optimal.

Berdasarkan literatur internasional, disebut Soetarso dalam Huraerah (2007: 67), ketelantaran anak secara umum dibagi dalam dua kelompok, yaitu:

a. Ketelantaran yang disebabkan kondisi keluarga yang miskin, tetapi hubungan sosial dalam keluarga normal. b. Ketelantaran yang disebabkan karena kesengajaan, gangguan jiwa dan/ atau ketidakmengertian keluarga/orang tua, atau hubungan sosial dalam keluarga tidak normal. Termasuk dalam kelompok ini adalah anakanak yang membutuhkan perlindungan khusus, terutama karena perlakuan salah, baik secara fisik maupun seksual.

Dalam Undang-undang No 4 Tahun 1979 Tentang Kesejahteraan Anak, anak terlantar didefinisikan sebagai anak yang karena suatu sebab orang tuanya melalaikan kewajibannya sehingga kebutuhan anak tidak dapat terpenuhi dengan wajar, baik secara rohani, jasmani maupun sosial.

Lebih lanjut dalam Peraturan Menteri Sosial RI Nomor 08 Tahun 2012 Tentang Pedoman Pendataan dan Pengelolaan Data Penyandang Masalah Kesejahteraan Sosial dan Potensi dan Sumber Kesejahteraan Sosial dikatakan bahwa Anak Terlantar adalah seorang anak berusia 6 tahun sampai dengan 18 tahun, meliputi anak yang mengalami perlakuan salah dan ditelantarkan oleh orang tua/keluarga atau anak kehilangan hak asush dari orang tua/keluarga.

Dalam berbagai kajian tentang tindak pelanggaran terhadap hak anak, kasus penenlantaran anak masuk dalam kategori child abuse. Secara teoritis penelantaran adalah sebuah tindakan baik disengaja maupun tidak disengaja yang membiarkan anak tidak terpenuhi kebutuhan dasarnya (sandang, pangan, papan). Penelantaran pada anak tidak mengenal alasan motivasi ataupun intensi. Ciri-ciri yang menandai seorang anak dikategorikan telantar menurut Bagong Suyanto (2010) adalah:

a. Mereka biasanya berusia 5-18 tahun, dan merupakan anak yatim, piatu, atau yatim piatu.

b. Anak yang telantar adalah anak yang biasanya lahir dari hubungan seks di luar nikah dan kemudian mereka tidak ada yang mengurus karena orang tuanya tidak siap secara psikologis maupun ekonomi untuk memelihara anak yang dilahirkannya.

c. Anak yang kelahirannya tidak direncanakan atau diinginkan oleh kedua orang tuannya atau keluarga besarnya, sehingga cenderung rawan diperlakukan salah.

d. Meskipun kemiskinan bukanlah satu-satunya penyebab anak ditelantarkan dan tidak selalu pula keluarga miskin akan menelantarkan anaknya. Tetapi bagaimanapun harus diakui bahwa tekanan kemiskinan dan kerentanan ekonomi keluarga akan menyebabkan 
kemampuan mereka dalam memberikan fasilitas dan memenuhi hak anaknya menjadi sangat terbatas.

e. Anak yang berasal dari keluarga yang broken home, korban perceraian orang tuanya, anak yang hidup ditengah kondisi keluarga yang bermasalah - pemabuk, kasar, korban PHK, terlibat narkotika dan sebagainya.

Lebih lanjut Bagong Suyanto (2010) menyampaikan bahwa dari segi penampakan fisik, perlakuan, dan ancaman yang dihadapi anak-anak yang terlantar barangkali memang tidak sedramatis ketika kita mendengar atau menyaksikan anak-anak menjadi korban tindak kekerasan, seperti anak perempuan korban perkosaan atau anak-anak yang menjadi korban tindak kekerasan: terluka secara fisik, atau bahkan dianiaya hingga tewas. Tetapi, dari segi sosial dan psikologis, ancaman yang dihadapi anak terlantar sesungguhnya tidak kalah berbahaya. Di tingkat individu, anak-anak sejak dini terbiasa ditelantarkan, maka jangan heran jika mereka kemudian tumbuh menjadi anak yang inferior, rendah diri, atau sebaliknya menjadi agresif dan nakal utuk menarik perhatian orang-orang disekitarnya. Bahkan, tidak mustahil anak-anak yang ditelantarkan kemudian terlibat dalam tindakan kriminal karena kesalahan asuhan.

Tindakan penelantaran anak baru memperoleh perhatian publik secara lebih serius tatkala korban-korban tindak penelantaran itu jumlahnya makin meluas, makin banyak, dan menimbulkan dampak yang tak kalah mencemaskan bagi masa depan anak. Seorang anak yang sejak usia dini kurang memperoleh kasih sayang, ditelantarkan begitu saja atau bahkan menjadi objek tindak kekerasan oleh orang tuanya sendiri, maka jangan heran ketika anak-anak mulai tumbuh menjadi remaja satu persatu mulai muncul masalah.

Berdasarkan Keputusan Menteri Sosial RI Nomor 27 Tahun 1984 terdapat beberapa karakteristik atau ciri-ciri anak terlantar yaitu:

a. Anak (laki-laki/ perempuan) berusia 5 -18 tahun

b. Tidak memilik ayah, karena meninggal (yatim), atau ibu karena meninggal tanpa dibekali secara ekonomis untuk belajar, atau melanjutkan pelajaran pada pedidikan dasar.

c. Orang tua sakit-sakitan dan tidak memilliki tempat tinggal yang tetap, penghasilan tidak tetap dan sangat kecil serta tidak mampu membiayai sekolah anaknya. d. Orang tua tidak memiliki tempat tinggal yang tetap baik itu rumah sendiri maupun rumah sewaan.

e. Tidak memiliki ibu ataupun bapak (yatimpiatu), dan saudara, serta belum ada orang lain yang menjamin kelangsungan pada tingkatan dasar dalam kehidupan anak.

f. Tidak terpenuhi kebutuhan dasarnya.

g. Anak yang lahir karena tindak perkosaan, tidak ada yang mengurus dan tidak mendapat pendidikan.

\subsection{Keluarga dan Fungsi Keluarga}

Keluarga merupakan lingkungan sosial terdekat, dan sangat signifikan berpengaruh terhadap perkembangan dan kehidupan secara umum. Keluarga didefinisikan sebagai unit terkecil, dimana unit sosial tersebut terdiri dari unsur "orang tua" dan "anak". Menurut Lemme (1995), keluarga adalah suatu sistem sosial independen, di mana di dalamnya terdapat hubungan yang saling mempengaruhi dan timbal balik antara anggota dalam sistem tersebut.

Penjelasan yang diungkapkan Lemme tersebut memberikan pengertian keluarga yang lebih luas dari sekedar unit sosial yang beranggotakan 'orang tua' dan 'anak' saja. Dalam pengertian ini, suatu sistem yang terdiri dari orang tua, anak, kakek, nenek, paman, bibi atau individu lain yang memiliki interaksi dan hubungan interdependen dapat dipandang sebagai suatu keluarga. Keluarga adalah unit dalam masyarakat yang bertanggungjawab untuk menjamin terpenuhinya kebutuhan dasar anak. Cara terbaik membantu anak adalah dengan mendukung kapasitas keluarganya untuk merawat anak-anak. Mempertahankan keluarga akan meningkatkan keterikatan antara orangtua dan anak serta adikkakak.

Keluarga mempunyai sistem jaringan interaksi yang lebih bersifat hubungan interpersonal, dimana masing-masing anggota dimungkinkan mempunyai intensitas hubungan satu sama lain, antara ayah dengan ibu, ayah dengan anak, ibu dengan anak, maupun antara anak dan anak.

Keluarga merupakan lembaga dasar dalam masyarakat dan disebut juga sebagai masyarakat terkecil. Keluarga juga menjadi lingkungan pertama yang dijumpai oleh seorang anak ketika dilahirkan di dunia. William J Goode (1995: 3-4) menyatakan, setiap keluarga mempunyai kedudukan utama, yaitu: 
a. Berfungsi sebagai pengantara dengan masyarakat luas

b. Berfungsi sebagai pemenuhan kebutuhan yang beragam agar dapat bertahan. Perlu adanya sikap memotivasi pribadi-pribadi untuk mengabdikan kepentingan umum sehingga masyarakat dapat bertahan dan juga sebagai kontrol sosial.

c. Berfungsi sebagai jaringan sosial yang besar.

d. Berfungsi sebagai pendukung masyarakat agar dapat bertahan demikian juga sebaliknya keluarga dapat bertahan karena dukungan masyarakat.

Abraham H. Maslow menjelaskan, keluarga merupakan tempat dan berfungsi untuk memenuhi berbagai kebutuhan manusia mulai dari kebutuhan primer (sandang, pangan, papan), kebutuhan rasa aman, kebutuhan untuk mencintai dan dicintai, kebutuhan harga diri, sampai dengan kebutuhan aktualisasi diri (Goble, 1994: 41).

Keluarga merupakan satuan sosial yang paling mendasar, karena dari keluarga masyarakat itu dibentuk, tanpa adanya keluarga tidak akan ada masyarakat, bangsa, dan negara. Dikatakan sebagai bentuk masyarakat kecil karena keluarga memiliki syarat-syarat yang sama dengan masyarakat pada umumnya. Dalam suatu keluarga terdapat sejumlah manusia yakni suami, istri, dan anak. Unsur tempat juga merupakan unsur keluarga, yaitu rumah tempat tinggal, tempat terjadinya interaksi, dan juga dalam keluarga ada sejumlah kegiatan baik berupa kegiatan seharihari dalam rumah maupun kegiatan-kegiatan yang dilakukan oleh anggota-anggota keluarga dari luar rumah dalam rangka mencapai tujuan bersama.

Hampir dalam setiap masyarakat, keluarga merupakan pusat kehidupan secara individu, dimana di dalamnya terdapat hubungan yang intim dalam derajat yang tinggi. Terlepas dari soal hubungan yang intim ini, keluarga selain sebagai unit yang berfungsi untuk melanjutkan keturunan, dan secara universal keluarga juga merupakan penanggung jawab dalam hal pemeliharaan dan pendidikan anak. Tidak itu saja keluarga merupakan unit perawatan bagi anggota yang sakit atau yang mengalami musibah. Di banyak masyarakat, keluarga juga berfungsi sebagai unit ekonomi, terutama dalam hal pemenuhan kebutuhan pangan, sandang, dan beberapa kebutuhan materi lainnya.

Subandiroso (1987:21) mengklasifikasikan fungsi keluarga sebagai berikut:

a. Melindungi setiap anggota keluarga.

b. Memberi pendidikan kepada anak. c. Melakukan kegiatan ekonomi.

d. Mengasuh serta membesarkan anak.

Sedangkan Yadi Mulyadi, dkk (1995:108) mengemukakan fungsi keluarga sebagai berikut:

a. Melakukan keturunan atau reproduksi

b. Afeksi atau kasih sayang

c. Sosialisasi

d. Ekonomi

e. Pengawasan / kontrol sosial

f. Proteksi atau Perlindungan

Selanjutnya, menurut McIver \& Page fungsi keluarga adalah merawat, memelihara, melindungi anak dalam rangka sosialisasinya agar mereka mampu mengendalikan diri dan berjiwa sosial. (Khairuddin, 1985: 9)

\subsection{Hak dan Kebutuhan Anak}

Hak anak secara universal telah ditetapkan melalui Sidang Umum PBB pada tanggal 20 November 1959 dengan diproklamirkannya Deklarasi Hak Anak. Dengan deklarasi tersebut diharapkan semua pihak baik individu, orang tua, organisasi sosial, pemerintah, dan masyarakat mengakui hak-hak tersebut dan mendorong semua upaya untuk memenuhinya. Ada sepuluh prinsip tentang hak anak menurut deklarasi tersebut, yaitu:

- Prinsip 1: Setiap anak harus menikmati semua hak yang tercantum dalam deklarasi ini tanpa terkecuali, tanpa perbedaan dan diskriminasi.

- Prinsip 2: Setiap anak harus menikmati perlindungan khusus, harus diberikan kesempatan dan fasilitas oleh hukum atau oleh peralatan lain, sehingga mereka mampu berkembang secara fisik, mental, moral, spritual, dan sosial dalam cara yang sehat dan normal.

- Prinsip 3: Setiap anak sejak dilahirkan harus memiliki nama dan identitas kebangsaan.

- Prinsip 4: Setiap anak harus menikmati manfaat dari jaminan sosial.

- Prinsip 5: Setiap anak baik secara fisik, mental, dan sosial mengalami kecacatan harus diberikan perlakun khusus, pendidikan dan pemeliharaan sesuai dengan kondisinya.

- Prinsip 6: Setiap anak bagi perkembangan pribadinya secara penuh dan seimbang memerlukan kasih sayang dan pengertian.

- Prinsip 7: Setiap harus menerima pendidikan secara cuma-cuma dan atas dasar wajib belajar.

- Prinsip 8: Setiap anak dalam situasi apapun harus menerima perlindungan dan bantuan yang pertama. 
- Prinsip 9: Setiap anak harus dilindungi dari setiap bentuk keterlantaran, tindakan kekerasan dan eksploitasi.

- Prinsip 10: Setiap anak harus dilindungi dari setiap praktik diskriminasi berdasarkan rasial, agama, dan bentuk-bentuk lainnya.

Disamping itu, dalam pasal 2 UndangUndang Nomor 4 Tahun 1979 Tentang Kesejahteraan anak, disebutkan:

a. Anak berhak atas kesejahteraan, perawatan, asuhan dan bimbingan berdasarkan kasih sayang, baik dalam keluarganya maupun dalam asuhan khusus untuk tumbuh dan berkembang dengan wajar.

b. Anak berhak atas pelayanan untuk mengembangkan kemampuan dan kehidupan sosial, sesuai dengan kebudayaan dan kepribadian bangsa, untuk menjadi warga negara yang baik dan berguna.

c. Anak berhak atas pemeliharaan dan perlindungan baik semasa kandungan maupun sesuadh dilahirkan.

d. Anak berhak atas perlindungan terhadap lingkugan hidup yang dapat membahayakan atau menghambat pertumbuhan dan perkembangan dengan wajar.

Sedangkan dalam pasal 4 ayat 1 disebutkan bahwa anak yang tidak mempunyai orang tua berhak memperoleh asuhan dari negara atau orang atau badan. Kemudian pasal 5 ayat 1 menyebutkan bahwa anak yang tidak mampu berhak memperoleh bantuan agar dalam lingkungan keluarganya dapat tumbuh dan kembang secara wajar.

Disamping menguraikan hak-hak anak melalui UU Nomor 4 Tahun 1979 diatas, Pemerintah Indonesia telah meratifikasi Konvensi Hak Anak (KHA) PBB yang dikukuhkan melalui Keppres Nomor 39 Tahun 1990. Menurut KHA yang diadopsi dari Majelis Umum PBB tahun1989, setiap anak tanpa memandang ras, jenis kelamin, asal-usul keturunan, agama maupun bahasa, mempunyai hak-hak yang mencakup empat bidang:

a. Hak Atas Kelangsungan Hidup, menyangkut hak atas tingkat hidup yang layak dan pelayanan kesehatan.

b. Hak Untuk Berkembang, mencakup hak atas pendidikan, informasi, waktu luang, kegiatan seni dan budaya, kebebasan berfikir, berkeyakinan dan beragama, serta anak cacat atas pelayanan, perlakukan dan perlindungan khusus. c. Hak Perlindungan, mencakup perlindungan atas segala bentuk eksploitasi, perlakuan kejam, dan perlakuan sewenang-wenang dalam proses peradilan pidana.

d. Hak Partisipasi, meliputi kebebasan untuk menyatakan pendapat, berkumpul dan berserikat, serta hak untuk ikut serta dalam pengambilan keputusan yang menyangkut dirinya.

KHA merupakan instrumen hukum internasional yang paling lengkap, karena mencakup seluruh aspek hak anak, mencakup hak politik, ekonomi, dan sosial serta tanggung jawab dari negara, masyarakat, dan orang tua untuk memenuhi hak-hak itu.

Selanjutnya, sejak ditetapkannya Undangundang Nomor 23 Tahun 2002 Tentang Perlindungan Anak pada tanggal 22 Oktober 2002, perlindungan bagi anak Indonesia telah memiliki landasan hukum yang relatif lengkap dan cukup banyak dicantumkan dalam undang-undang tersebut. Pasal-pasal yang berkaitan dengan hakhak anak tersebut adalah sebagai berikut:

a. Pasal 4: Setiap anak berhak untuk hidup, tumbuh, berkembang, dan berpartisipasi secara wajar sesuai harkat dan martabat kemanusiaan, serta mendapat perlindungan dari kekerasan dan diskriminasi.

b. Pasal 5: Setiap anak berhak atas suatu nama sebagai identitas diri dan status kewarganegaraan.

c. Pasal 6: Setiap anak berhak untuk beribadah menurut agamanya berpikir, dan berekspresi sesuai dengan tingkat kecerdasan dan usiannya, dalam bimbingan orang tua.

d. Pasal 7: (1) Setiap anak berhak untuk mengetahui orang tuanya, dibesarkan, dan diasuh oleh orang tuanya sendiri. (2). Dalam hal karena suatu sebab orang tuanya tidak dapat menjamin tumbuh kembang anak, atau anak dalam keadaan terlantar, maka anak tersebut berhak diasuh atau diangkat sebagai anak asuh atau anak angkat oleh orang lain sesuai dengan ketentuan peraturan perundang-undangan yang berlaku.

e. Pasal 8: Setiap anak berhak atas pelayanan kesehatan dan jaminan sosial sesuai dengan kebutuhan fisik, mental, spritual dan sosial.

f. Pasal 9: Setiap anak berhak memperoleh pendidikan dan pengajaran dalam rangka pengembangan pribadinya dan tingkat kecerdasannya sesuai dengan minat dan bakatnya. 
g. Pasal 11: Setiap anak berhak untuk beristirahat dan memanfaatkan waktu luang, bergaul dengan anak sebaya, bermain, berekreasi, berkreasi sesuai dengan minat, bakat dan tingkat kecerdasannya demi perkembangan diri.

Untuk menjamin pertumbuhan fisiknya, anak membutuhkan makanan yang bergizi, pakaian, sanitasi dan perawatan kesehatan. Semasa kecil, mereka memerlukan pemeliharaan dan perlindungan dari orangtua sebagai perantara dengan dunia nyata. Untuk menjamin perkembangan psikis dan sosialnya, anak memerlukan aktualisasi diri, dan pengembangan intelktual. Sejak dini, mereka perlu pendidikan dan sosialisasi dasar, pengajaran tanggungjawab sosial, peran-peran sosial, dan keterampilan dasar agar menjadi warga masyarakat yang bermanfaat (Suharto, 1997: 636).

Kegagalan dalam proses pemenuhan kebutuhan tersebut akan berdampak negatif pada pertumbuhan fisik dan perkembangan intelektual, mental dan sosial anak. Anak bukan saja akan mengalami kerentanan fisik akibat gizi dan kualitas kesehatan buruk, melainkan juga mengalami hambatan mental, lemah daya nalar, dan bahkan perilaku-perilaku maladaptif, seperti: autis, "nakal", susah diatur, yang kelak mendorong mereka menjadi manusia "tidak normal: dan pelaku kriminal (Suharto, 1997: 363364).

Pertumbuhan dan kesejahteraan fisik, intelektual, emosional, dan sosial anak akan mengalami hambatan, sebagaimana dikatakan Soetarso dalam Huraerah (2007), jika:

a. Kekurangan gizi dan tanpa perumahan yang layak.

b. Tanpa bimbingan dan asuhan.

c. Sakit dan tanpa perawatan medis yang tepat

d. Diperlakukan salah secara fisik

e. Diperlakukan salah dan dieksploitasi secara seksual.

f. Tidak memperoleh pengalaman normal yang menumbuhkan perasaan dicintai, diinginkan, aman, dan bermartabat

g. Terganggu secara emosional, karena pertengkaran keluarga yang terus-menerus, perceraian dan mempunyai orang tua yang menderita gangguan/ sakit jiwa.

h. Dieksploitasi, bekerja berlebihan, terpengaruh oleh kondisi yang tidak sehat dan demoralisasi

\subsection{Kesejahteraan Sosial Bagi Anak}

Istilah pelayanan berasal dalam bahasa Inggris, "service". HAS Moenir (2002:26-27) mendefinisikan pelayanan sebagai kegiatan yang dilakukan oleh seseorang atau sekelompok orang dengan landasan tertentu dimana tingkat pemuasannya hanya dapat dirasakan oleh orang yang melayani atau dilayani, tergantung kepada kemampuan penyedia jasa dalam memenuhi harapan pengguna. Pelayanan pada hakikatnya adalah serangkaian kegiatan, karena itu pelayanan dilakukan secara rutin, berkesinambungan. Meliputi seluruh kehidupan organisasi dalam masyarakat. Pelayanan sosial kesejahteraan terhadap anak merupakan suatu rangkain kegiatan atau aktivitas yang dilakukan oleh orang tua, keluarga, kelompok maupun masyarakat dan bahkan pemerintah dalam memenuhi seluruh aspek kebutuhan bagi anak. .

Anak mempunyai kedudukan yang sangat penting dalam kehidupan bermasyarakat, berbangsa, dan bernegara karena anak adalah tunas yang akan tumbuh dan berkembang menjadi bagian generasi penerus perjuangan dalam rangka pencapaian cita-cita bangsa. Sebagai generasi penerus maka anak perlu dirawat, dibina dan ditingkatkan kesejahteraannya agar dapat tumbuh dan mengembangkan kepribadian dan kemampuan serta keterampilan dalam melaksanakan peranan dan fungsi dalam kehidupan sesuai dengan pertumbuhan usianya. Dalam kesejahteraan sosial tercakup pula pelayanan kesejahteraan sosial bagi anak, agar mereka dapat berkembang dengan sehat dan wajar sebagaimana layaknya. Kesejahteraan anak sangat penting untuk membantu menyejahterakan pertumbuhan dan perkembangan anak dan meningkatkan kehidupan keluarga

Undang-Undang No. 4 Tahun 1979 menyatakan bahwa kesejahteraan anak adalah suatu tatanan kehidupan dan penghidupan anak yang dapat menjamin pertumbuhan dan perkembangannya dengan wajar baik secara rohani, jasmani maupun secara sosial (Bab I Pasal $1)$.

Anak-anak yang mengalami masalah kesejahteraan akan mengalami kesulitan untuk tumbuh dan berkembang secara wajar. Anak-anak yang mengalami hal tersebut memerlukan pelayanan dan bimbingan sehingga dapat melaksanakan tugas kehidupannya sesuai dengan harapan masyarakat.

Kesejahteraan sosial bagi anak ditujukan untuk membantu memperbaiki kondisi anak dan 
keluarga untuk memperkuat kembali, melengkapi, atau menganti fungsi orang tua yang tidak mampu melaksanakan tugasnya sebagaimana mestinya dengan mengubah institusi-institusi sosial yang ada atau membentuk institusi baru (Johnson \& Schwatz, 1991: 20).

Kesejahteraan anak merupakan bidang khusus dalam kesejahteraan sosial. Sehubungan dengan masalah-masalah kesejahteraan sosial, mengenai ketidakmampuan orang tua untuk memnuhi kebutuhan anak sebagai akibat dari kemiskinan dan adanya interaksi yang kurang memadai di dalam keluarga, maka perlindungan anak sangat diperlukan sebagai salah satu upaya untuk mensejahterakan anak. Kesejahteraan anak di Indonesia dijamin oleh undang-undang yaitu Undang-undang Nomor 4 Tahun 1979 Tentang Kesejahteraan Anak. Pada dasarnya perlindungan anak merupakan bidang kesejahteraan sosial, sedangkan kesejahteraan anak merupakan aspek kesejahteraan sosial sehingga aspek perlindungan anak meupakan aspek kesejahteraan sosial juga. (Khaizu, 2009)

Terkait dengan pemahaman diatas tentang kesejahteraan anak yang merupakan aspek dari kesejahteraan sosial maka untuk mengatasi permasalahan sosial anak dengan melakukan beberapa strategi pelayanan kesejahteraan sosial bagi anak, sebagaimana dikemukakan oleh Suharto (1997: 373-375), ada tujuh strategi yang dilakukan untuk pelayanan kesejahteraan anak, namun dalam hal ini penulis hanya mencantumkan empat strategi dari tujuh sesuai dengan lokal konteks yaitu:

a. Child Based Service, strategi ini menempatkan anak sebagai baris penerima pelayanan. Anak yang mengalami luka-luka fisik dan psikis perlu segera diberikan pertolongan yag bersifat krisis baik perawatan medis, konseling, atau dalam keadaan tertentu anak dipisahkan dari keluarga yang mengancam dan membahayakan kehidupannya.

b. Institutional Based Service, anak yang mengalami masalah ditempatkan di lembaga/panti. Pelayanan yang diberikan meliputi fasilitas tinggal tetap menetap, pemenuhan kebutuhan dasar, perlindungan, pendidikan dan pelatihan keterampilan, serta program rehabilitasi sosial lainnya.

c. Family Based Service, keluarga dijadikan sasaran dan medium utama pelayanan. Pelayanan ini diarahkan pada pembentukan dan pembinaan keluarga agar memiliki kemampuan ekonomi, psikologis, dan sosial dalam menumbuhkembangkan anak,sehingga mampu memecahkan masalahnya sendiri dan menolak pengaruh negatif yang merugikan dan membahayakan.

d. Community Based Service, strategi yang menggunakan masyarakat sebagai pusat penanganan ini bertujuan untuk meningkatkan kesadaran dan tanggungjawab masyarakat agar ikut aktif dalam menangani permasalahan anak.

\section{Metodologi Penelitian}

\subsection{Jenis Penelitian}

Penelitian ini menggunakan metode kualitatif dengan jenis penelitian deskriptif analitis untuk menggambarkan tentang faktor dan dampak anak yang diterlantarkan.

\subsection{Waktu dan Tempat Penelitian}

Penelitian dilakukan di Kota Ambon, dengan pertimbangan bahwa sebagai ibukota provinsi dan juga pusat perekonomian kota ini mendorong munculnya berbagai macam permasalahan sosial, salah satunya adalah anak terlantar. Penelitian ini dilakukan pada bulan November 2015 - Februari 2016.

\subsection{Teknik Pengumpulan Data}

Teknik pengumpulan data dalam penelitian ini adalah observasi dan wawancara serta studi kepustakaan.

\subsection{Teknik Analisa Data}

Teknik analisa data yang diterapkan dalam penelitian ini adalah analisis data kualitatif yang dideskripsikan dalam bentuk uraian.

\section{Hasil Dan Pembahasan}

4.1. Faktor-Faktor Penyebab Anak Diterlantarkan a. Faktor Keluarga

Perpisahan orang tua sangat memengaruhi kehidupan sosial seorang anak. Kehidupan keluarga yang tidak lengkap menciptakan kondisi yang miris bagi pertumbuhan dan perkembangan anak. Pemicu bercerainya pasangan suami-istri atau orang tua disebabkan karena adanya perselingkuhan yang dilakukan oleh suami terhadap istri dan juga kepergian suami atau ayah tanpa memberitahukan dan meninggalkan istri dan anak. Selain kehilangan ayah juga, anak-anak kehillangan kedua orang tua yang meninggalkan mereka dalam lingkungan keluarga besar. Kepergian orang tua terutama ibu disebabkan oleh keinginan untuk memenuhi kebutuhan keluarga. 
Perceraian orang tua selalu mengisahkan luka bagi anak dan anak menjadi korban saat kedua orang tuanya bercerai. Idealnya, anak-anak tumbuh dalam sebuah keluarga dengan kehadiran ayah-ibu. Saat perceraian terjadi, anak tinggal dengan salah satu orang tua bahkan tidak dengan keduanya. Kondisi ini dialami oleh 10 orang anak yang orang tuanya bercerai, sementara 10 anak ditelantarkan oleh ayah mereka saat mereka masih kecil dan bahkan sejak bayi ditinggalkan oleh ayahnya, dan 10 anak yang lain ditinggalkan oleh kedua orang tua karena kematian. Kepergian kedua orang tua menyebabkan anak hidup bersama dengan keluarga dari ayah dan atau ibu seperti kakek, nenek, paman dan tante dan kebutuhan serta keperluan secara materi maupun non materi dibiayai oleh keluarga yang mengasuh.

Perceraian dan kehilangan orang tua menjadi salah satu faktor resiko yang mendorong anakanak pergi ke jalan atau menjadi terlantar. Perceraian atau perpisahan orang tua yang kemudian menikah lagi atau memiliki teman hidup baru tanpa ikatan penikahan sering membuat anak menjadi frustasi. Rasa frustasi ini akan semakin bertambah ketika anak dititipkan ke salah satu anggota keluarga orang tua mereka atau tatkala anak yang biasanya lebih memilih tinggal dengan ibunya merasa tidak mendapatkan perhatian, justru menghadapi perlakuan buruk ayah tiri atau pacar ibu.

Disamping perceraian yang menjadi penyebab utama, faktor kehamilan yang tidak diakui juga merupakan penyebab tidak lengkapnya sebuah keluarga, dimana anak tidak mendapatkan pengakuan ayahnya sehingga anak tersebut kemudian ditelantarkan bersama dengan ibunya. Ketidakmampuan orang tua menyediakan kebutuhan dasar, ditolak orang tua, salah perawatan atau kekerasan di dalam rumah, terpisah dengan orang tua, keterbatasan merawat anak. Hal ini dipengaruhi pula oleh meningkatnya masalah keluarga yang disebabkan oleh kemiskinan, pengangguran, perceraian, kawin muda maupun kekerasan dalam rumah tangga. Melemahnya keluarga besar, dimana keluarga besar tidak mampu lagi membantu keluargakeluarga inti, diakibatkan oleh pergeseran nilai, kondisi ekonomi dan kebijakan pembangunan pemerintah.

\section{b. Faktor Pendidikan}

Masalah paling mendasar yang dialami oleh anak terlantar adalah kecilnya kemungkinan untuk mendapatkan kesempatan dibidang pendidikan yang layak. Hal ini disebabkan karena beberapa aspek. Pertama, ketiadaan biaya, tidak adanya biaya untuk menyekolahkan anak-anak disebabkan karena tidak adanya pendapatan yang tetap dan bahkan tidak menyediakan secara khusus biaya pendidikan sehingga anak menjadi putus sekolah karena hasil pendapatan dari pekerjaan hanya dapat memenuhi kebutuhan sehari-hari keluarga. Kedua, keterbatasan waktu. Keterbatasan waktu yang dimiliki oleh anak dalam bersekolah dikarenakan waktu mereka telah dipakai untuk berpartisipasi dalam membantu keluarga memenuhi kebutuhan dasar dengan bekerja sebagai pencuci kuburan, tukang ojek, jualan tas kresek di pasar, menjajakan kue, dan menjadi supir oto, dan juga menjaga adik ketika ibunya sedang tidak di rumah. Ketiga, rendahnya kemauan untuk belajar, dari hasil temuan di lapangan terlihat bahwa anak-anak terlantar atau diterlantarkan memiliki kemauan yang rendah dalam belajar. Hal ini sangat dipengaruhi oleh waktu yang telah tersita dalam membantu ekonomi keluarga (bekerja), kondisi tubuh yang lelah setelah berjualan menyebabkan mereka tidak memiliki motivasi atau semangat untuk belajar. Keempat, adanya pemahaman yang salah terhadap pendidikan. Yang melatarbelakangi pemahaman anak-anak terlantar terhadap pendidikan yang keliru disebabkan karena mereka memiliki kemudahan dalam mendapatkan uang dalam memenuhi kebutuhan keluarga dan juga menambah uang jajan mereka sehingga pendidikan tidak menjadi perioritas bagi mereka. Terakhir, kurangnya perhatian dari lingkungan. Perhatian yang kurang dari orang tua maupun keluarga terhadap pendidikan anak membuat anak tidak menikmati pendidikan yang seharusnya, situasi ini yang menjadikan pendidikan bukan hal yang penting bagi keluarga.

\section{c. Faktor Ekonomi}

Dari kasus yang ditemukan ternyata masalah ekonomi menjadi faktor utama anak-anak mengalami keterlantaran karena kondisi keluarga tidak dapat memenuhi kebutuhan hidup mereka. Seperti yang diungkapkan anak-anak tersebut bahwa mereka dapat makan hanya 2 kali dalam sehari, itupun kalau orang tua mereka mendapatkan uang lebih dari hasil pekerjaannya. Namun jika kondisi keuangan orang tua tidak mencukupi maka mereka hanya bisa makan hanya satu kali saja, bahkan tidak makan. Faktor ekonomi menjadi penyebab bagi orang-orang tidak mampu memenuhi kehidupannya secara 
baik. Pendapatan yang kecil juga dipengaruhi oleh sebagian orang tua yang bekerja dan ada yang tidak bekerja. Bentuk pekerjaan yang dijalankan oleh orang tua beragam. Pekerjaan orang tua/ orang tua pengganti adalah pedagang, tukang cuci, ibu rumah tangga, pembantu rumah tangga, dan supir dengan penghasilan rata-rata $\mathrm{Rp}$ 100-700 ribu per bulan, hasil ini sangat tergantung dari penjualan atau pekerjaan yang mereka lakukan. Pendapatan keluarga yang kurang dalam memenuhi kebutuhan hidup, membuat anak-anak terlibat membantu kehidupan ekonomi keluarga sehari-hari. Hasil kerja mereka diserahkan kepada orang tua atau orang tua pengganti.

\section{d. Faktor Kesehatan}

Sehat merupakan harapan semua manusia, tanpa terkecuali anak-anak terlantar. Anak yang memiliki kondisi sehat, bukan saja secara fisik namun secara psikis dan juga sosial, dapat berkembang dan bertumbuh menjadi seorang anak yang cerdas dan bermartabat. Masalah kesehatan merupakan masalah utama yang harus menjadi perhatian serius dalam setiap kehidupan manusia. Artinya, seseorang akan menentukan aktivitas kehidupan sehari-hari tergantung dari kesehatannya. Kesehatan seseorang tidak bisa hanya dilihat dari kondisi fisik saja, tetapi harus dilihat secara terpadu. Seseorang yang dikatakan sehat adalah mampu melakukan segala aktivitas kesehariannya dan dapat berperan secara maksimal dalam kehidupan sehari-hari, baik sebagai pribadi maupun sebagai anggota masyarakat. Manusia sehat adalah manusiamanusia yang mampu memanfaatkan potensipotensi yang ada pada dirinya untuk mencapai tujuan hidup.

Kesehatan yang baik dan prima memungkinkan seseorang hidup lebih produktif baik secara sosial maupun ekonomi. Oleh karena itu, kesehatan menjadi salah satu hak dan kebutuhan dasar yang harus dipenuhi agar setiap individu dapat berkarya dan menikmati kehidupan yang bermartabat. Realitas yang ditemukan ternyata kondisi anak-anak terlantar sangat bertolak belakang dengan konsep sehat. Artinya, anak-anak terlantar tidak memperoleh pelayanan kesehatan yang memadai. Hal tersebut terjadi karena faktor:

1) Kesadaran akan kesehatan yang kurang. Sebagian anak beranggapan bahwa orang tua atau orang tua pengganti tidak memiliki kepedulian saat kondisi tubuh mereka dalam keadaan sakit. Hal ini dipicu oleh karena orang tua lebih fokus mencari uang untuk menutupi kebutuhan hidup keluarga sehingga kesehatan anak bukan menjadi prioritas bagi orang tua atau orang tua pengganti. Selain itu juga, kondisi ekonomi atau penghasilan hanya cukup untuk makan sehingga untuk melakukan pengobatan atau pemeriksaan ke dokter atau ke rumah sakit tidak dilakukan. Untuk meredakan rasa sakit yang dialami, anak-anak tersebut diberikan obat yang diperoleh dengan membeli di toko dekat rumah mereka. Menurut orang tua atau orang tua penganti, saat ini jasa pelayanan kesehatan makin lama makin mahal. Tingginya biaya kesehatan makin sulit dijangkau oleh masyarakat, terutama keluarga dari anak-anak terlantar. Dengan kata lain, faktor ekonomi keluarga menyebabkan kurangnya kesadaran orang tua akan kesehatan anak sehingga mereka tidak memiliki akses yang lebih untuk mendapat pelayanan kesehatan yang layak.

2) Lingkungan rumah yang tidak sesuai dengan standar kesehatan. Rumah sebagai tempat bagi setiap individu mendiami dan melepaskan kepenatan setelah beraktivitas seharian di luar rumah. Situasi yang miris atau cukup memprihatinkan yang dialami oleh anak-anak terlantar adalah tidak layaknya tempat untuk mereka bertumbuh dan berkembang. Hal ini disebabkan oleh tempat tinggal yang mereka ditempati sangat kecil dengan ukuran yang hanya dapat ditempati oleh dua atau tiga orang serta kondisi air yang sangat jauh dari higenis menjadi penyebab timbulnya berbagai penyakit. Situasi yang tidak kondisif dan lingkungan yang tidak aman menciptakan suasana tidak nyaman bagi anak. Dari subyek yang diteliti, pada umumnya mereka mengalami gangguan kesehatan secara fisik, dari batuk, pilek, demam, tipus, asma, hingga paru-paru basah. Saat dalam situasi sakit, mereka tidak dapat ke dokter atau rumah sakit dan hanya dirawat oleh ibu/ ayah atau orang tua pengganti, bahkan ada diantara mereka tidak dipedulikan.

Masalah kesehatan, merupakan masalah utama yang harus menjadi perhatian serius dalam setiap kehidupan manusia. Artinya, seseorang dalam menjalankan aktivitas kehidupan seharihari tergantung dari kesehatannya. Kesehatan seseorang tidak bisa hanya dilihat dari kondisi fisik saja, tetapi harus dilihat secara terpadu. Seseorang yang dikatakan sehat adalah mampu melakukan segala aktivitas kesehariannya dan 
dapat berperan secara maksimal dalam kehidupan sehari-hari, baik sebagai pribadi maupun sebagai anggota masyarakat. Manusia sehat adalah manusia-manusia yang mampu memanfaatkan potensi-potensi yang ada pada dirinya untuk mencapai tujuan hidup.

\subsection{Deskripsi Dampak Anak yang Ditelantarkan}

Berbicara tentang dampak artinya ada sesuatu yang dialami atau dirasakan oleh seseorang karena tindakan orang lain, sehingga tindakan tersebut berakibat secara langsung maupun tidak langsung terhadap perkembangan individu dalam berinteraksi dengan lingkungan sosialnya. Dalam penelitian ini, dampak yang ditimbulkan atau yang dialami oleh anak terlantar .adalah sebagai berikut:

\section{a. Dampak Fisik}

Setiap anak memilliki hak untuk bertumbuh sesuai dengan usianya. Perkembangan dan pertumbuhan yang baik sangat didukung oleh nutrisi yang masuk kedalam tubuh sehingga anak tumbuh menjadi pribadi yang sehat secara jasmani. Anak-anak yang ditelantarkan oleh orang tua terutama ibu, sangat berpengaruh terhadap penampilan fisik mereka. Kondisi tubuh yang tidak terurus seperti kuku yang panjang dan kotor, rambut yang tidak terurus bagi anak cowok, dan mengunakan pakaian yang tidak layak. Dampak yang paling signifikan adalah anak tumbuh dan berkembang tidak sesuai dengan usianya artinya anak tersebut melaksanakan atau melakukan suatu aktivitas tidak sesuai dengan kondisi tubuhnya. Selain itu, dampak fisik dari penelantaran adalah anak tidak mendapatkan makanan, tempat tinggal dan juga pakaian untuk digunakan secara layak dan optimal.

\section{b. Dampak Psikologis}

Anak yang mengalami gangguan psikologis disebabkan oleh perlakuan salah ataupun tindakan yang diterima dari orang lain sehingga menyebabkan mereka menjadi pribadi yang tidak berani untuk menyampaikan atau mengucapkan apa yang mereka rasakan atau inginkan. F. Heider, sebagaimana dikutip David O. Sears, dkk (1992: 98), menjelaskan, perilaku manusia dipengaruhi oleh faktor internal berupa motif, emosi, sikap, kemampuan, kesehatan dan keinginan, sedangkan faktor eksternal dipengaruhi oleh lingkungan umum, orang yang diajak berinteraksi, tekanan sosial, peran yang dipaksakan dan sebagainya.

Dari hasil temuan, anak dalam kategori ini, mereka selalu berada dalam perasaan yang tertekan, sedih, kecewa, marah bahkan merasa minder dan malu terhadap apa yang terjadi pada diri mereka dan bahkan memiliki perilaku yang tidak sesuai dengan usia mereka sehingga membuatnya tertekan. Kemarahan dan perkataan hinaan yang selalu mereka terima merupakan perlakuan secara langsung yang diperoleh dari orang-orang terdekat mereka.

Kehilangan salah satu orang tua memiliki kontribusi yang sangat besar dalam kehidupan pribadi anak, dimana anak merasakan kekosongan figur atau peran seorang ayah maupun ibu atau kedua-duanya. Hal ini memberikan dampak langsung bagi anak dalam bertindak maupun bersikap serta membentuk pribadi yang pendiam sehingga mereka tidak dapat mengekspresikan kehidupan pribadinya secara terbuka. Disamping itu, dampak lain dari kehilangan figur ayah atau ibu dan atau kedua-duanya, anak-anak melakukan suatu aktivitas untuk menarik perhatian orang lain untuk memperhatikan apa yang mereka lakukan untuk mencari perhatian dari orang sekelilingnya.

\section{c. Dampak Sosial}

Anak sebenarnya merupakan bagian yang tidak terpisahkan dalam kehidupan di lingkungan sosialnya di mana anak-anak mendapatkan perlindungan sosial dalam lingkungan keluarga dan lingkungan sekitarnya. Namun berdasarkan temuan lapangan, interaksi dan relasi sosial antara anak dan orang tua berjalan tidak efektif. Telah dijelaskan sebelumnya bahwa perceraian ataupun tidak adanya pengakuan dari orang tua dalam hal ini ayah terhadap anak berpengaruh terhadap hubungan dengan lingkungannya. Artinya, ketika anak tumbuh dan berkembang dalam lingkungan sosialnya maka anak tersebut akan tetap dan selalu berinteraksi dengan teman-teman sebayanya, orang tua dan masyarakat. Namun, orang tua maupun masyarakat memperlakukan mereka sebagai "orang-orang terbuang". Keberadaan anak terlantar dianggap sebagai kelompok yang mengganggu sehingga mereka seringkali diperlakukan secara diskriminatif.

Perlakuan yang salah dari masyarakat, menyebabkan anak mencari tempat yang "aman" untuk menerima keberadaan mereka. Kurangnya kepedulian dari orang tua dan juga masyarakat menyebabkan anak tidak memiliki kebebasan dalam mengekspresikan kemampuan untuk bersosialisasi secara baik. 


\subsection{Analisis}

Permasalahan anak dari tahun ke tahun semakin mengalami peningkatan terlebih lagi masalah anak terlantar yang jumlahnya semakin meningkat. Hal ini membuktikan bahwa apa yang telah dilakukan belum maksimal sehingga kebutuhan anak belum tercapai secara optimal. Berdasarkan apa yang dikemukakan oleh penulis di atas, persoalan anak terlantar yang begitu beragam dengan berbagai dampak yang dialami dalam fase-fase pertumbuhan dan perkembangannya memberikan suatu gambaran bahwa anak-anak terlantar yang berada di Kota Ambon membutuhkan perlindungan dan peningkatan kesejahteraan dalam berbagai aspek kehidupan mereka, sehingga mereka dapat berkembang dan bertumbuh secara maksimal. Persoalan yang dialami anak terlantar di Kota Ambon dari aspek fisik, psikis, ekonomi maupun sosial menunjukkan bahwa pemenuhan akan kebutuhan dasar tidak terpenuhi secara layak.

Perceraian orang tua atau kehilangan figur ayah/ ibu dan atau kedua-duanya merupakan faktor pemicu yang menyebabkan anak-anak kehilangan kasih sayang dan perhatian sehingga mendorong mereka untuk mencari kehidupan di luar rumah. Tidak berfungsinya keluarga dalam menjaga keharmonisan dan keseimbangan hubungan diantara anggota keluarga berdampak terhadap hubungan personal antara anak dan orang tua. Persoalan lain yang dialami anak adalah mereka harus meninggalkan bangku sekolah akibat perceraian orang tua dan faktor ekonomi keluarga yang tidak dapat memenuhi kebutuhan untuk bersekolah. Selain itu, kondisi kesehatan yang menyebabkan anak berada dalam suatu fase perkembangan yang tidak sesuai dengan usia mereka.

Permasalahan yang dihadapi anak dalam masa pertumbuhannya memberikan dampak terhadap interaksinya dengan lingkungan baik internal maupun eksternal. Penelantaran merupakan salah satu bentuk dari kekerasan dengan cara membiarkan anak dalam situasi gizi buruk, kurang gizi (malnutrisi), tidak mendapatkan perawatan maksimal, memaksa anak menjadi anak jalanan, memaksa untuk bekerja membantu orang tua, berjualan, menjadi pembantu rumah tangga, pemulung dan jenis pekerjaan lainnya yang membahayakan pertumbuhan dan perkembangan anak. Perlakuan salah yang diterima oleh anak karena orang tua atau orang tua penganti belum memahami anak sebagai bagian yang penting dalam kehidupan sosial yang sesungguhnya. Akibatnya, anak didorong untuk melakukan pekerjaan orang dewasa untuk memenuhi kebutuhan keluarga. Selain itu, perlakuan salah yang juga diberikan oleh orang tua adalah tidak sepenuhnya memberikan perlindungan dan kenyamanan bagi anak dalam hal ini kasih sayang dan perhatian sebagaimana mestinya. Dengan terabaikannya hak-hak anak dalam pemenuhan kebutuhan dasar mereka maka akan berpengaruh terhadap proses perkembangan dan pertumbuhan secara fisik, psikis maupun sosial.

Pemenuhan hak-hak anak sebagaimana terinternalisasi dalam Undang-undang Perlindungan anak sangat jelas menguraikan tentang tanggung jawab orang tua dalam pertumbuhan anak sejak anak dalam kandungan sampai mencapai usia 18 tahun. Disamping itu, keluarga sebagai unit terkecil yang terdiri dari orang tua merupakan tempat pertama anak mengenal dunia sehingga orang tua mempunyai kewajiban bertanggung jawab terhadap masa depan anak-anaknya. Pemenuhan hak-hak tersebut, khususnya kebutuhan akan perlindungan, meliputi perlindungan dalam bidang kesehatan, pendidikan agama, dan kesejahteraan sosial.

Disadari bahwa permasalahan anak terlantar merupakan dilema, artinya di satu sisi orang tua telah mengabaikan pemenuhan kebutuhan dasar anak secara fisik, psikis, ekonomi maupun sosial sehingga anak tidak memperoleh hak sebagaimana telah diamanatkan dalam UU maupun KHA. Namun di sisi lain, tidak dapat dipungkiri bahwa kondisi orang tua yang memprihatinkan karena tidak memiliki pekerjaan ataupun penghasilan yang tetap untuk mencukupi kebutuhan anak. Disamping itu persoalan anak terlantar bukan saja menjadi tanggung jawab orang tua, namun menjadi tanggung jawab pemerintah maupun masyarakat seperti yang telah diamanatkan dalam Undang-Undang Dasar 1945.

Sinergitas antara keluarga (orang tua), masyarakat maupun pemerintah di tingkat pusat maupun daerah memiliki kewajiban untuk membantu anak terlantar memperoleh kesempatan dalam meraih masa depan yang lebih baik. Peran pemerintah sangat penting dalam upaya peningkatan sumber daya manusia melalui pendidikan. Pasal 31 UUD 1945 menyatakan bahwa setiap warga negara berhak untuk memperoleh pendidikan yang layak atau bermutu, artinya anak terlantar sebagai bagian dari warga negara juga memiliki hak untuk memperoleh pendidikan yang bermutu dari tingkat dasar 
sampai ke perguruan tinggi. Disamping pendidikan, hal yang juga penting adalah kesehatan. Jika seorang anak memiliki kesehatan yang tidak sesuai dengan usia perkembangannya, maka akan berpengaruh terhadap kecerdasan intelektual emosional, sosial, bahkan spritual anak tersebut.

\section{Kesimpulan dan Saran}

\subsection{Kesimpulan}

Berdasarkan temuan penelitian tentang problematika anak terlantar di Kota Ambon yang diuraikan diatas maka dapat disimpulkan sebagai berikut:

a. Masalah keluarga dalam hal ini perceraian dan perlakuan yang salah menjadi faktor pemicu anak ditelantarkan sehingga pemenuhan akan kebutuhan belum dipenuhi secara optimal baik dari aspek fisik, psikis, ekonomi maupun sosial.

b. Isu pendidikan anak belum menjadi prioritas orang tua disebabkan kurangnya pemahaman akan pentingnya pendidikan sehingga mereka tidak mendorong anak sekolah melainkan mendorong untuk bersama-sama membantu perekonomian keluarga agar dapat memenuhi kebutuhan hidup sehari-hari.

c. Beragam masalah yang dihadapi anak terlantar memberikan dampak langsung maupun tidak langsung terhadap tumbuh kembangnya untuk hidup secara layak dan normal sesuai dengan usianya.

d. Masyarakat belum memiliki kepedulian terhadap persoalan anak terlantar menyebabkan isu anak terlantar belum merupakan suatu masalah yang dilihat secara serius.

e. Kebijakan pemerintah daerah terhadap penanganan anak terlantar belum menyentuh ke akar masalah sehingga isu anak menjadi persoalan sosial yang terus menjadi sasaran kerja dari pemerintah.

\subsection{Saran}

Berdasarkan kesimpulan tersebut, maka disarankan sebagai berikut :

a. Perlu adanya pengembangan program yang berbasis home industry yang diperuntukan bagi orang tua ataupun keluarga untuk memaksimalkan potensi yang mereka miliki agar dapat membantu pemenuhan kebutuhan keluarga terutama pemenuhan kebutuhan anak.

b. Perlu adanya sosialisasi tentang pendidikan anak bagi orang tua agar mereka dapat memahami arti penting pendidikan bagi anakanaknya.

c. Perlu adanya home based bagi anak-anak terlantar, hal ini penting bagi anak agar dapat mengembangkan kreativitas dalam melakukan hal-hal yang inovatif untuk meningkatkan pengetahuan mereka.

d. Perlu membangun pemahaman dan kepedulian bersama tentang isu anak terlantar di antara tokoh-tokoh sentral dalam masyarakat sehingga isu-isu yang terkait dengan anak dapat teratasi.

e. Perlu adanya pengembangan model penanganan dari pemerintah, khususnya dinas sosial tentang anak terlantar di Kota Ambon.

\section{REFERENSI}

Barker, Robert L. 1999. The Social Work Dictionary. Washington DC: National Association of Social Workers (NASW) Press.

Damanik, Juda dan Cynthia Pattiasina. 2008. Buku Pintar Pekerja Sosial Jilid I (Terjemahan). Jakarta: BPK Gunung Mulia dan Building Professional Social Work In Developing Countries.

Goble, Frank G. 1994. Mazhab Ketiga: Psikologi Humanistik Abraham Maslow (Terjemahan). Yogyakarta: Kanisius.

Goode, William J. 1995. Sosiologi Keluarga. Jakarta: Bumi Aksara.

Gosita Arief. 1989. Masalah Perlindungan Anak. Jakarta: Penerbit Akademia Presindo.

Gunarsah D.Singgih. 1982. Dasar dan Teori Perkembangan Anak. Jakarta: PT BPK Gunung Mulia.

Huraerah Abu. 2007. Child Abuse: Kekerasan Terhadap Anak (Edisi Revisi). Bandung: Penerbit Nuansa.

Johnson, Louise C and Charles L. Schwartz. 1991. Social Welfare: A Response to Human Needs. Boston: Allyn \& Bacon. 
Khairuddin. 1985. Sosiologi Keluarga. Yogyakarta: Nur Cahaya.

Khaizu, Ingata. 2009. Upaya-upaya Perlindungan Oleh Organisasi Sosial Keagamaan Lokal Bagi Anak yang Berada Pada Pemukiman Rawan Untuk Tereksploitasi Secara Ekonomi dan Seksual (Skripsi). Depok: FISIP UI

Kusnandi, Rusmil. 2004. Penganiayaan dan Kekerasan Terhadap Anak (Makalah, Tidak Diterbitkan). Bandung.

Lemme, BH. 1995. Development in Adulthood. USA: Allyn \& Bacon.

Mulyadi, Yadi, dkk (ed). 1995. Sosiologi. Jakarta: Yudistira.

Moenir, HAS. 2002. Manajemen Pelayanan Umum di Indonesia. Jakarta: Bumi Aksara.

Ronawaty, Anasiru. 2011. Implementasi ModelModel Kebijakan Penanggulangan Anak Jalanan di Kota Makasar.

Santrock, John W. 1995. Life Span Development: Perkembangan Masa Hidup (Edisi Kelima, Terjemahan). Jakarta: Erlangga

Sears, David O; Jonatan L. Freedman; L. Anne Peplau. 1992. Psikologi Sosial (Edisi Kelima, Terjemahan). Jakarta: Erlangga.

Subandiroso. 1987. Sosiologi Antropologi I (Program Pengetahuan Budaya dan IlmuIlmu Sosial). Klaten: Intan Pariwara.

Suharto, Edi. 1997. Pembangunan, Kebijakan Sosial dan Pekerjaan Sosial: Spektrum Pemikiran. Bandung: Lembaga Studi Pembangunan STKS.

Suharto, Edi. 2010. Pendidikan dan Praktik Pekerjaan Sosial di Indonesia: Melacak Masa Lalu, Merajut Masa Depan. Bandung: STKS PRESS.

Suyanto, Bagong. 2010. Masalah Sosial Anak. Jakarta: Kencana Prenada Media Group.
Walton, Elaine, Sanda- Beckler, Patricia, Mannes, Marc. Editors. 2001. Balancing FamilyCentered Services and Child Well-Being: Exploring Issues in Policy, Practice, Theory, and Research. New York: Columbia University Press.

Yohandarwati, dkk. 2003. Sistem Perlindungan Sosial: Suatu Kajian Awal. Jakarta: Direktorat Kependudukan, Kesejahteraan dan Pemberdayaan Perempuan, BAPPENAS.

Peraturan:

Keputusan Menteri Sosial RI Nomor 27 Tahun 1984 Tentang Bantuan Terhadap Anak yang Kurang Mampu, Anak Cacat dan Anak Bermasalah. Jakarta: Departemen Sosial Republik Indonesia, 1984.

Konvensi Hak Anak. 2002. Deklarasi Dunia Mengenai Kelangsungan Hidup Perlindungan dan Pengembangan Anak. Jakarta: Departemen Sosial RI, 2002.

Peraturan Menteri Sosial RI Nomor 08 Tahun 2012 Tentang Pedoman Pendataan dan Pengelolaan Data Penyandang Masalah Kesejahteraan Sosial dan Potensi dan Sumber Kesejahteraan Sosial. Jakarta: Kementerian Sosial Republik Indonesia, 2012.

Undang-Undang No. 4 Tahun 1979 Tentang Kesejahteraan Anak.

Undang-Undang No. 23 Tahun 2002 Tentang Perlindungan Anak.

Undang-Undang No. 11 Tahun 2009 Tentang Kesejahteraan Sosial.

*Nancy Rahakbauw, Dosen S1 Ilmu Kesejahteraan Sosial FISIP Universitas Kristen Indonesia Maluku (UKIM) Ambon

Email: nancyrahakbauw@yahoo.com 